\title{
RODZINA KOŚCIOŁEM DOMOWYM WEDŁUG ŚW. JANA CHRYZOSTOMA
}

Cheác opracowác teologi ̨z rodziny według ojców Kościoła, moźna albo szuká u nich teoretycznyc! założen, jakie wysnuwajaz Pisma św. i w forwie miej lub więcej wykończonej przedstawiaja w traktatach, czy w jakiejkolwiek imej formie. Noźna tez ujać temat bardziej egzystencjalnie, zjawiskowo i przypatrzeć siq, jak przedstawiaje oni konkretne colziny chrześcijańskie w swoich czasach. Takich zaś opisów jest wiele.

Pierwsza forna nastracza niemale trulności, bo teoretycznych rozważai na temat rodziny jest u jjcúw niewiele. Bez trudności można by pisać na temat małzeństwa i wychowania u ojców, i te dwa zagadnienia były jus przez badaczy wielokrotnie podejmowane. dateriału na temat hałzeństwa i wychowania dzieci jest równiez sporo. Nie widać natoriast tekstów, które by zajęły się problemem teologii rodziny .

Druga forma, a wi ̨c konkretne opisy rodzin chrześcijańskich, miałaby oparcie źródłowe przede wszystkim w mowach, jakie 0jcowie wygłaszali na pogızebach osób świeckich. Mniej wyuajne są tu biografie samych ojców, gdyż autorzy tych opracowań, zafascynowani urokiem wielkich postaci, szeroko wypowiadali sie na temat ich dokonań na polu nauki, duszpasterstwa, czy organizacji kościelnej, a o ich nłodości, o klibacic rodzinnyir, w jakín wzrastali, byli na ogół nad wyraz zwięzli. Więcej materiału dostarczaja autobiografie samych 0jców. Jest ich niewiele, ale za to są najwyższej próby. Hystarczy tu wsporanieć "fiyznania" św.Augustyna, żeby poznać atmosfere rodziny chrześcijańskiej, żeby ujrzeć niewymierna wprost rolę matki honiki, która nadawała ton całej rodzinie, bo była głęboko świadoma, jakie są jej obowi zzki wobec męża poganina i zaołızkanego syna. Podobnie hożna by powiedzieć o roli Nonny, matki Grzegorza z Nazjanzu, czy Antuzie, matce Jand Chryzostoma, tyle ze pozycja tych dwu ostatnich matek nie ma dokumentacji tak wysokiej klasy, jak Monika.

W'artykule spróbuję zastosować pierwsza netodę. Pewne przesłanki, i tylko przesłanki, do teologii rodziny postaran się wydobyć 
z dzleł św.Jana Chryzostoma. On chyba najwięcej spośród wszystkich ojców mówił jeżeli nie wprost o rodzinie, to o sprawach rodzinnych. Nikt tak często nie zabierał głosu na temat powszechnego powołania do świętości, co on. Totez nie bez racji nazwano go "kaznodzieja doskonałości ludzi świeckich"/Prediger der Laienvollkommenheit/.

Chryzostom jest kaznodzieja $i$ pisarzem na wskroś praktycznym, nie ma wprawdzie polotu Augustyna, ale trzymając się realiów życia, chce tchnąć w codzienny jego bieg ducha Ewangelii. Dalej, jest on kaznodzieja w całej pełni biblijnym. Swoje nauki zawsze wysnuwa z Pisma św., a w jego penetracji jest mistrzem nad mistrze. 0 jednym zdaniu z Pisma św. potrafił głosié cały cykl kazań.

Jednym z takich zlań jest pozdrowienie Pryscylli i Akwili. Zacznijmy od tekstu z I Listu do Koryntian. "Pozdrawiaja was pisze św.Paweł - kościoły Azji. Pozdrawiaja was serdecznie w Panu Akwila i Pryscylla razem ze zbierajzcym sie w ich domu Kościołem"

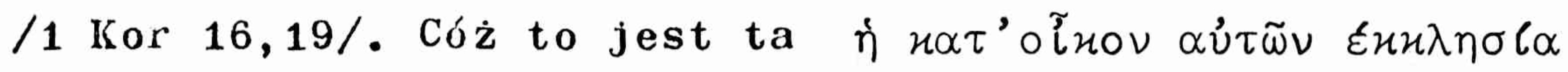

- w Wulgacie "domestica ecclesia?" czyli kościół domowy, zgromadzenie domowe? Nie tyle sam dom, mieszkanie tych chrześcijan, ile i to przede wszystkim - ludzie tam mieszkajz̨cy i w ogóle cała atmosfera chrześcijańska domu. Nie budowla czyni Kościół, lecz plebs sancta, która "gromadzi się", bo to właśnie oznacza grecki termin

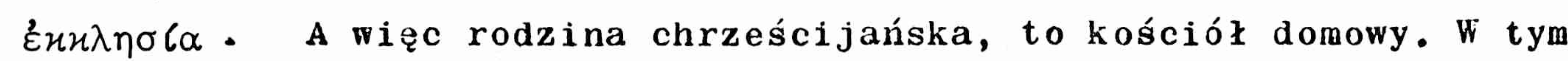
kościele panuje absolutna równość, znikaja podziały na panów i niewolników.

Przy okazji podobnego pozdrowienia, na początku Listu do Filemona ${ }^{1}$, pisał Jan Chryzostom:

"Nie pominął nawet niewolników; wiedział bowiem, że nieraz i słowa niewolników zdołaja wpłynąć na pana /.../. Przeciez nazwa zgromadzenia nie pozwala panom czuć się dotkniętymi, jeżeli zostanä do niego zaliczeni razem $z$ niewolnikami, albowiem $z \mathrm{~g}$ o $\mathrm{m}$ a $\mathrm{d}$ e $n i$ e $k$ o śc i e 1 n e nie zna różnicy między panem i niewolnikiem, określajac jednych i drugich tylko na podstawie dobrych i złych uczynków. Jeżeli więc gdzie jest zgromadzienie, nie oburzaj się na to, że wspólną z tobą przemowa objęty został niewolnik: "W Chrystusie Jezusie bowien nie ma ani niewolnika ani wolnego"/Gal $2,28 / 2$.

1 Flm 1-2: "Paweł ... do ... Kościoła[gromadzącego sie] w tym domu" = Biblia Tysiaclecia; "y zgromadzeniu które jest w domu twoim" = tłum. Wujka.

2 In ep. ad Philemonem hom. 1,1, PG 62.705. t1um. T.Sinko/Sw.Jan 
Dalszy krok zrobił Chryzostom $w$ "Womentarzu de Listów św. Pawła do Rzymian" 3 nawiązując do tego samego pozdrowienia z Listu do Filemona. Dlaczego jeszcze dom chrześcijański jest kościołem? Na kościół przemieniaja go członkowie rodziny: Filemon, jego żona Apia nazwana przez św.Pawła "miłą" i wszyscy inni domownicy. Czynia z domu kościół, jeżeli sami sa wypróbowani w cnocie i działaja apostolsko, starająe się pozyskać dla Chrystusowej wiary wszystkich naleźących do starożytnej "familia", a wszystkim gościom, przychodniom $i$ wędrowcom głoszą Chrystusa. Nie każdy dom jest kościołem, podkreśla z naciskiem Chryzostom, lecz tylko ten, "w którym zakorzeniona jest głęboka pobożność i wielka bojaźń Boża"4 rodzina jest pierwszaz komórką, w której rodzi się świętość i to świętość apostolska. Do starania się o nią nawoływał Chryzostom stale i bez znużenia. Wywoływało to u niektórych słuchaczy protesty. Jak to? - mówił do niego niejeden Antiocheńczyk - przeciez nie jestem mnichem, mam żone i dzieci, tysiazce spraw czeka na załatwienie, jestem w ciągłym ruchu, gdzie więc czas i ochota o staranie się o taka doskonałość? To rzecz mnichów i tych, co zdala od trosk i kłopotów poświęcili się wyłacznie Bogu. W góry każesz nam się wynosić i pustelnikiem zostać?

Głosiciel doskonałości laikatu tak na te zarzuty odpowiadał:

"Ogromnie ubolewam, że sądzicie, jakoby skromność i czystość obywiązywała tylko innichów. Chrystus wydał te same prawa dla wszystkich. Gdy mówi:

"Wszelki, który patrzy na niewiastę, aby jej pożądał", nie nówi do pustelnika, ale do tego, który ma żonę; albowiem te nasze okoliczne góry, nie były jeszcze zamieszkane przez takich męźów /.../. Nie bronię żenić się, ani nie przeszkadzam zabawić się, ale chcę, żeby siz to działo z przyzwoitością, a nie z hańbą, grzechem i tysiącznymi przewinieniami. Nie nakazuję bowiem, abyście się udawali na góry i pustynie, ale mówię, żeby ten, cow mieście mieszka, by $¥$ dobry, przyzwoity i skromny. Albowiem wszystkie prawa mamy z pustelnikami wspólne, prócz małżeństwa; ale 1 w tym nakazuje Paweł we wszystkim ich naśladować mówiąc: "Przemija postać świata tego, aby i ci, co żony

Złotousty, Ilomilie na listy pasterskie św.Pawła i na List do Filemona. Kraków 1949/ 368-369.

3 In ep. ad lomanos hor. 30,3, $\mathrm{PG} 60,664$.

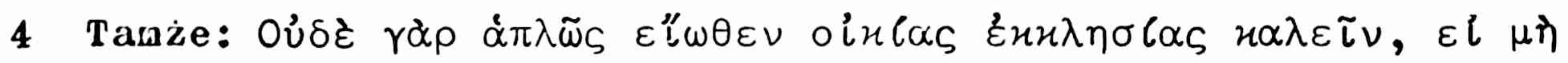


mają, byli jakoby ich nie mieli"/1 Kor $7,29 /$. Dlatego mówi - nie nakazuję wam, abyście udawali się na wierzchołki gór; wprawdzie zyczyłbym sobie tego, bo miasta naśladują to, co sia działo w Sodomie, ale nie zinuszam do tego. Zostań w domu z dziećmi i z żoną; ale nie obrażaj żony, nie psuj dzieci, nie wprowadzaj do domu zepsucia z teatru. Czy nie słyszałeś, co Pawez mówi: "Mąż nie rozporzizdza własnym ciałem, ale żona" $/ 1$ Kor 7,4/ $i$ w ten sposób nadaje obojgu jednakie prawa. Ty, jeśli żona zawsze chodzi do kościoła, karcisz ja mocno za to; ale jeśli sam całymi dniami wysiadujesz w teatrze, czy nie zasługujesz na naganę? Jesteś zatroskany o skromność żony, jesteś zbytecznie i drobiazgowo zapobiegliwy i zabraniasz jej nawet potrzebnego wyjścia, a przy tym myślisz, ze tobie wszystko wolno. Ale tego Paweł ci nie przyznaje, bo tę samą wolność daje i żonie /.../. Dlaczego opowiadantem rzeczy zasłyszanych na ulicy żonę i córkę wstydem oblewasz? Naucz się milczeć, żeby takich bezecności nie opowiadać" 5 .

Takie postulaty świętości stawiał Chryzostom wielkomiejskiej rodzinie chrześcijańskiej. Powszechne wezwanie do świętości: męża, żony, dzieci $i$ służby. Obowizzzek wzajemnego pomagania sobie na drodze do świetości, a nie przeszkadzania.

Zdumiewa siz Chryzostom nad parą małżenską Pryscylli i Akwili: "Zabrali Apollosa z sobą i wyłożyli mu dokładniej droge Pańską" / Dz 18,26/. "Nie gańmy przeto małżeństwa - wyjaśnia mówca w homilii "Salutate Priscillam" - 1 nie uważajmy go za przeszkode na drodze do cnoty, bo nie są nimi ani stan małzeński, ani wychowywanie dzieci, ani prowadzenie gospodarstwa domowego, ani praca zawodowa. oto mamy tu męża 1 żonę; pracuja przy warsztatach i zajmuja się rzemiosłem dając dowód bardziej wypróbowanej cnoty, niż ci, co przebywaja w klasztorach. /.../A skąd to wiadomo? - zo słów, jakich Paweł o nich uźywa 1 uźwał, ponadto z pochwał, jakimi ich obsypuje. A dalej z faktu, ze u nich zamieszkiwał, nie dzień, nie dwa, lecz pełne dwa lata, wynika, ze wysoko oceniał zalety ich dusz./.../Apostołowie stosowali się do nakazu Chrystusa: "Gdy wejdziecie do jakiegoś miasta lub domu,

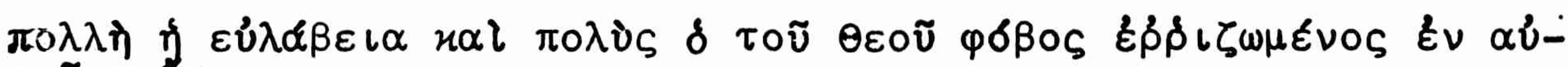
IOIs $\varepsilon i \eta \eta$

5 In Mat thaeum hom. 7,7, PG 57,80-81, por. tłum. J.Krystyniacki /Sw. Ojca naszego Jana Chryzostoma wykład Ewangeli1 św. Mateusza w 90 homiliach zawarty, t.1-3, Lwów 19032/, t.1, 87-88. 
zapytajcie, kto wim jest godny i u niego sie zatrzymajcie" Mt 10, 11. Dla Pawła oni właśnie byli godni, a jeśli dla Pawła, to i dla aniołów. Dlatego bez wahania ten ich domek nazywam niebem i Kościo$¥ e \mathrm{~m}^{\prime \prime} 6$

Warto się tu też zastanowić nad jednym jeszcze szczegółem. Dlaczego to $w$ pozdrowieniu wiście do Kzymian najpierw pozdrawia Paweł Pryscyllę, a potem dopiero jej małżonka Akwilę? Nie zrobił tego bez racji, albowiem dostrzegł w niej większą gorliwość niż u Akwil1. Ten mój wywód - ciągnie dalej Chryzostom - nie jest tylko przypuszczeniem, lecz ma oparcie w Dziejach Apostolskich, które wyránie dają do zrozumienia, ze Pryscylla wyszła z inicjatywa, żeby uczonego zreszta Apollosa gruntowniej pouczyć o nauce Chrystusa. Bo doprawdy kobiety czasów apostolskich nie wkładały całej swej troski w strojenie się, szminkowanie itd., lecz to wszystko precz odrzuciwszy, o to tylko zabiegały, aby stanąć do współpracy z Apostołami, i zdobywać takie same owoce, jak oni. Podobnie pozdrawia Paweł Persyde, "która wiele trudu poniosła w Panu" / $\mathrm{kz} 16,12 /$, tak samo Marię i Tryfenę/iz 16,6,12/. Ale jak to pogodzić z innymi słowami Apostoła: "Niewieście nauczać nie pozwalam" /1 Tym 2,12/. Ma to zastosowanie wówczas, gdy mąż wyznaje tę samą religię. Natomiast gdy jest niewierny i pozostaje w błędzie, nie pozbawia jej prawa nauczania. I nawiązując do zdania św.Pawła: "Jeśli jakaś żona ma niewiernego męźa i ten chce razem z nią mieszkać, niech się z nim nie rozstaje. Uświęci się bowiem mąż niewierzący dzį̨ki swej żonie" /1 Kor 7,13-14/. Za św.Pawkem twierdzi Chryzostom, że żona zbawi męźa pouczając go, objaśniając mu prawdy Boże 1 doprowadzajac do wlary, jak to zrobiła Pryscylla z Apollosem. Gdy mówi: Kobiecie nie pozwalam nauczać, mówi o nauczaniu z ambony, mówi o przemawianiu do ludu, a to jest obowiazkiem kapłanów. Nie zakazywał natomiast prywatnych zachęt, rad 1 pouczeń. Gdyby tego zakazał, nie pochwaliłby za to Pryscylli. Niech to usłyszą męzowie, niech usłysza kobiety. Te, żeby ja naśladowały, ci zaś, żeby nie stali się mniej aktywni od żon. Jakąż mężowie mieć będą wymówkę i czy zasłuza na przebaczenie, kiedy kobiety wykazują taki zapał i taką mądrość 
ży c i ową?

Idźmy krok dalej. Niezmordowany w pochwałach tej pary małżenskiej, Chryzostom przystępuje do objaśnienia kolejnych słów Pawła: "Pozdrówcie współpracownikótv ... którzy za moje życie nadstawiali swe głowy"/Rz 16,4/. Ci skromni, prości,ubodzy, ale pobożni i bardzo gorliwi małżonkowie stawali w obronie Pawła narazając swe życie. Powiada Chryzostom, że gdyby tylko to jedno można było o nich powiedzieć, byliby już wszelkiej chwały najgodniejsi. Kto ratuje dowódcę, przyczynia się do ocalenia wojska; kto wyrwie z niebezpieczeństiva lekarza, przywraca zdrowie wielu ludziom; kto wyratował sternika z topieli morskiej, ten uratował okręt; kto staną $\mathbf{w}$ obronie nauczyciela narodów, ten stał się dobroczyńca całego świata. Zwróć jeszcze uwage, że oni țj. Akwila i Pryscylla, byli takimi nie tylko w stosunku do mistrza, ale i względem innych braci. Posłuchaj słów Pawła: "którym winienem wdzięczność nie tylko ja sam, ale 1 wszystkie kościoły nawróconych pogan" /Rz 16,4/. Co mówisz? Wszystkie koscioły pogan winne są wdzięczność tym ubogim namiotnikom, którzy zdołali zarobić zaledwie na skromne utrzymanie. I cóż wreszcie tych dwoje mogło pomóc tylu kościołom? Czy majątkiem, czy siła, czy wpływami u moźnych? Nic z tego nie mieli, natomiast mieli odwage stawić czoła wszystkim niebezpieczeństwom. Kościołowi pomagają nie tyle zarozumiali bogacze, ile ubodzy szerokiego serca. Zdanie to nie powinno nikogo dziwić, bo tak faktycznie jest $i$ doświadczenie to potwierdza. Bogacz lęka się o swe bogactwa, o służbę, o pola, bo boi się ich utraty i tyn sposobem pan nad wieloma rzeczami z konieczności staje się ich niewolnikiem. Natomiast ubogi, nie dręczony takimi troskami, jest Iwem, ogniem zionie, jest odwaźny i męźny, i łatwo podejmuje sie zadań, które moga pomóc Kościołowi, np. ukazania i myświetlenia prawdy, skarcenia kogos, czy czegokolwiek innego, co dla Chrystusa trzeba podjąć. On się niczego nie boi, bo niczego zabrać mu nie moga, więc gotów jest nawet krew przelać, gdyby zaszła taka konieczność. Taki jest mocniejszy od króla, tyrana, czy tłumu. Taki ma odwage powiedzieć prawdę, nie boi się. Iluź to było bogaczy za czasów Heroda, ilu moźnych. A kto zdobył się na odwagę, kto ujął się za prawem Bożym? Żaden bogacz, jeno ten ubogi Jan znad Jordanu. On pierwszy i jedyny zdobył się na odwage, zdemaskował cudzołożne łoże Heroda i publicznie go potępił. Taką samą postawę wykazał Eliasz stosunku do przeniewiercy Achaba. Tacy przynosza Kośc1ołowi 
daleko wį̧kszy pożytek, niż bogacze. Takimi byli Pryscylla i Akwila, którzy życie swe narażali w interesie św. Pawła ${ }^{7}$. Bujnie rozwijało się w tamtych czasach chrześcijaństuo, bo uczniowie byli tak ściśle złaczeni z nauczycielami, a nauczyciele z uczniami.

Streśćmy obecnie dotychczasowe wywody:

1. Rodzina chrześcijańska jest w swym wyaiarze religijnym $i$ w swej najgłębszej treści Kościołem domowym. Takie jej ujęcie opiera się na nauce św.Pawła, rozwijanej przez ojców Kościoła, a najlepiej i najjaśniej przez św.Jana Chryzostoma. Rodzina to "ecclesia domestica" /I Kor 16,19/. Te funkcje rodziny zapoczatkowuje chrzest, dlatego ojcowie energicznie zwalczaja jego odkładanie/procrastinatio baptismi/.

2. W rodzinie chrześcijańskiej panuje całkowita jedność i równość wszystkich. Nie ma w niej pana i niewolnika. W jej łonie wytwarza sie powszechne braterstwo.

3. Wszyscy w rodzinie powołani sa do świzztości i do dazzenia do doskonałości. Wezwanie Chrystusa w kazaniu na górze adresowane jest do wszystkich, a nie tylko do mnichów. Máa być wcielane w życie w ramach rodziny, w kościele domowym.

4. Rodzina chrześcijańska ma świadomość, że jest współpracowniczkaz Kościoła, przede wszystkim w dziedzinie apostolstwa środowiskowego.

5. Kobieta - zdaniem Jana Chryzostoma - odgrywa w rodzinie chrze-j ścijańskiej rolę pierwszoplanowa. dodzina i śrolowisko to jej ambona.

6. Lepsza atmosfera religijna panuje w rodzinie ubogiej. Ona bowien więcej pomaga Kościołowi, wykazując wizkszł inicjatywę $i$ odwagę

\section{Andrzej Bober SJ - Kraków}

\section{FAMILIAM CIRISTIANAM ICCLESIAM ESSE DOMESTICAḾ} E DICTIS S.JOANNIS CHIYSOSTOMT EXPLICATUR /Argumenturn/

Exilis et parva haec dissertatiuncula proposuit sibi delineare secundum doctrinan S.Joannis Chrysostomi idean faniliae caristianae prouti ecclesiae domesticae ad mentern S.Pauli/I Cor 16,19/. Initium et fundamentum ecclesiae domesticae est sacramentum baptisni ideoque S.Joannes et similiter alii Patres venementissime procrestinationem baptismi onpugnant. Fanilia christiana periectissina unitate et aequalitate gaudet. Omnes ad sanctitatein et periectionem assequendari sunt vocati, sermo enim Christi montanus ad omes dirigitur. Fariliae christianae sodales collaboratoces sunt censendi icclesiac. In apostolatu familiari primae partes sunt penes Pemina. Supradictae propositiones textisus S.Joannis uberrime illustrantur.

7 Tanże 3-5 /parafraza/, Ṕ̀ 51,192-194. 